(c) American Dairy Science Association, 2005.

\title{
Effect of Increased Milking Frequency in Early Lactation With or Without Recombinant Bovine Somatotropin*
}

\author{
M. J. VanBaale, D. R. Ledwith, J. M. Thompson, R. Burgos, R. J. Collier, and L. H. Baumgard \\ Department of Animal Sciences, University of Arizona, Tucson 85721
}

\begin{abstract}
Multiparous Holstein cows $(n=300)$ were assigned to 1 of 2 milking frequency treatments at parturition. Cows were either milked 6 times $(6 \times)$ or 3 times $(3 \times)$ daily to determine effects on early lactation milk yields and subsequent lactation persistency with or without use of recombinant bST (rbST). Treatments included a control group milked $3 \times$ and 3 groups milked $6 \times$ for either the first 7, 14, or 21 days in milk (DIM). Those 4 groups of cows all received rbST starting at 63 DIM. The fifth treatment group was also milked $6 \times$ for the first 21 DIM but those cows received no rbST during the entire lactation. All cows returned to $3 \times$ milking after their respective treatment periods ended. Cows milked $3 \times$ tended to produce more milk ( 43.2 vs. 41.5 and $41.0 \pm 1.1 \mathrm{~kg} / \mathrm{d}$ ) during the first 9 wk of lactation compared with cows milked $6 \times$ for 7 or 21 DIM, respectively. Group milk yields after wk 9 averaged $38.3 \pm 0.7 \mathrm{~kg} / \mathrm{d}$ and did not differ among various groups assigned to an increased milking frequency in early lactation. Percentages of milk fat $(3.8 \pm 0.12 \%)$ and protein $(2.9 \pm 0.06 \%)$ did not differ among treatments during the first 9 wk after calving. Early lactation milk yield $(41.9 \pm 1.2 \mathrm{~kg} / \mathrm{d})$ did not differ between the 2 groups of cows milked $6 \times$ for 21 DIM. However, cows subsequently administered rbST (at 63 DIM) produced more milk (38.8 vs. $34.2 \pm 0.9 \mathrm{~kg} / \mathrm{d}$ ) from wk 10 to 44 . The number of cows sent to the hospital during the 305-d trial for mastitis (97), digestive disorders (14), respiratory issues (9), lameness (22), or retained placenta (16), were not affected by treatments $\left(\chi^{2}=0.49\right)$. Under the conditions of this commercial dairy herd in Arizona, increasing milking frequency to 6 times daily for 7 to $21 \mathrm{~d}$ at the start of lactation conditions did not increase milk yield nor improve lactation persistency.
\end{abstract}

Received February 7, 2005.

Accepted July 5, 2005.

Corresponding author: Matthew J. VanBaale; e-mail: vanbaale@ ag.arizona.edu.

*This work was partially supported by the University of Arizona Experiment Station \#AZRT-137024-R-24-132 and the United Dairymen of Arizona.
(Key words: milking frequency, early lactation, somatotropin)

Abbreviation key: $\mathbf{2} \times, \mathbf{3} \times, \mathbf{4} \times, \mathbf{6} \times=$ milked 2,3 , 4, or 6 times daily, respectively, ECM = energy-corrected milk, IMF = increased milking frequency, $\mathbf{P P}=$ postpartum, $\mathbf{r b S T}=$ recombinant bST.

\section{INTRODUCTION}

Increasing milking frequency (IMF) has enhanced milk yield by 3.5 and $4.9 \mathrm{~kg} / \mathrm{d}$ when cows were milked $3(\mathbf{3} \times)$ or 4 times daily $(\mathbf{4} \times)$, respectively, compared with milking twice daily $(\mathbf{2} \times)$, and there was a tendency for milk fat and protein percentages to be reduced (Erdman and Varner, 1995). Although IMF has been demonstrated to increase milk synthesis during an established lactation (Erdman and Varner, 1995), its effects on milk yield when implemented for a short period $(<21 \mathrm{~d})$ during early postpartum $(\mathbf{P P})$ lactation are less clear. Bar-Peled et al. (1995), and Sanders et al. (2000) observed 7.3 and $6.0 \mathrm{~kg} / \mathrm{d}$ increases, respectively, in cows milked 6 times daily $(6 \times)$ for the first 42 DIM compared with cows milked $3 \times$. Hale et al. (2003) demonstrated that IMF $(4 \times$ vs. $2 \times)$ in early lactation ( 1 or 4 to 21 DIM) enhanced milk yield (>7 kg/d) during $4 \times$ milking and the increase persisted (post-IMF) for up to 252 DIM. In addition, a recent field study reported that IMF ( $6 \times$ vs. $3 \times$ ) in early lactation ( 1 to 21 DIM) increased milk yield $>8 \mathrm{~kg} / \mathrm{d}$, and the enhanced production remained $>5 \mathrm{~kg} / \mathrm{d}$ after IMF ended (Dahl et al., 2004). Overall, cows milked $6 \times$ during that field study produced $\sim 1118 \mathrm{~kg}$ more milk than cows milked $3 \times$ according to the first 10 monthly DHIA tests (Dahl et al., 2004). The aforementioned studies have shown that IMF of fresh cows will increase the milk yield during the IMF routine as well as throughout the entire lactation; even after the IMF routine has ceased (Bar-Peled et al., 1995; Sanders et al., 2000; Hale et al., 2003; Dahl et al., 2004). However, few studies have looked at the length of time IMF is required to have an immediate and subsequent effect on milk yield.

Somatotropin is secreted from the anterior pituitary gland and is found at higher concentrations in genetically superior cows (Kazmer et al., 1986). Recombinant bovine somatotropin (rbST) consistently increases milk 
Table 1. Composition of TMR fed during the experimental periods.

\begin{tabular}{lccc}
\hline & \multicolumn{3}{c}{ Diet } \\
\cline { 2 - 4 } Item & Close-up & Fresh & High \\
\hline DM \% & & & \\
Alfalfa hay & 33.8 & 36.7 & 25.0 \\
Alfalfa greenchop & 10.0 & 11.7 & 14.8 \\
Soybean meal & - & 2.6 & 3.3 \\
Corn silage & 25.3 & 14.6 & 12.2 \\
Molasses & - & 3.7 & 2.8 \\
Tallow & 0.3 & 0.5 & 0.9 \\
Energy II & 0.4 & 0.7 & 2.0 \\
Whole cottonseed & 2.4 & 4.4 & 4.8 \\
Barley & 24.3 & 21.4 & 31.5 \\
Vitamin/mineral premix & 2.3 & 3.7 & 2.7 \\
Nutrition composition & 3.6 & & \\
DM, \% & & 53.9 & 53.9 \\
CP, \% & 52.6 & 17.4 & 16.6 \\
RUP, \% of CP & 16.6 & 30.9 & 30.1 \\
NE, Mcal/kg & 26.6 & 0.76 & 0.82 \\
NDF, \% & 0.75 & 30.0 & 27.3 \\
ADF, \% & 32.7 & 4.4 & 17.6 \\
Fat, \% & 22.0 & 5.8 \\
NFC, \% & 3.4 & 37.5 & 40.5 \\
\hline
\end{tabular}

${ }^{1}$ Energy II, Bioproducts Inc., Fairlawn, OH.

${ }^{2}$ Vitamin and mineral mix formulated to meet or exceed NRC (2001) requirements.

${ }^{3}$ Calculated as $0.245 \times \%$ TDN -0.12 .

yield by 10 to $15 \%$ per cow (Bauman and Vernon, 1993). Combining IMF and rbST simultaneously enhanced the production response compared with each treatment alone, indicating that the 2 galactopoietic tools are additive and probably increase milk synthesis via different mechanisms (Knight et al., 1992; Speicher et al., 1994). However, no studies have evaluated the affects of IMF ( $6 \times$ vs. $3 \times$ ) during the first 7,14 , or $21 \mathrm{~d}$ PP, followed by rbST administration at 63 DIM on high-producing multiparous cows.

Study objectives were 1) to determine if cows milked $6 \times$ during early lactation would produce more milk during the IMF routine; 2) to evaluate the time necessary to milk cows $6 \times$ during early $\mathrm{PP}$ to have a positive impact on peak milk yield and lactation persistency, and 3) to determine if effects of IMF in early lactation and subsequent rbST administration during established lactation are additive.

\section{MATERIALS AND METHODS}

\section{Cows and Treatments}

Three hundred multiparous Holstein cows calving at a commercial dairy near Buckeye, $\mathrm{AZ}$, were randomly assigned to 1 of 5 treatment groups at freshening. All cattle freshened between November 4, 2003, and February 10,2004 . Cows were fed a TMR to provide $100 \%$ of NRC (2001) requirements daily at 0400, 1200, and 2000 $\mathrm{h}$ (Table 1), and were housed in dry lot corrals (permit-
Table 2. Impact of facility on cows milked 3 times $(3 \times)$ or 6 times $(6 \times)$ daily during early lactation.

\begin{tabular}{lcc}
\hline & \multicolumn{2}{c}{ Milking frequency } \\
\cline { 2 - 3 } Item & $3 \times$ & $6 \times$ \\
\hline Number of cows in pen & 39 & \\
$\quad$ Average & $20-70$ & $1-70$ \\
$\quad$ Range & 51 & 123 \\
Walking distance, m & 307 & 1480 \\
$\quad$ 1-way & & 390 \\
$\quad$ Per d & 195 & $270-450$ \\
$\quad$ Average out of pen, min & $180-225$ & $45-75$ \\
$\quad$ Range & & \\
Time milking, min & $60-75$ & \\
Range & & \\
\hline
\end{tabular}

ting $\left.49.2 \mathrm{~m}^{2} / \mathrm{cow}\right)$ with shades $(9.14 \mathrm{~m}$ wide by $3.96 \mathrm{~m}$ high; permitting $\left.44.5 \mathrm{~m}^{2} / \mathrm{cow}\right)$. Cows milked $6 \times$ were housed in a separate pen from cows milked $3 \times$ (during the IMF routine; $\leq 21 \mathrm{DIM}$ ) and both pens were located near $(87 \pm 36 \mathrm{~m})$ the milking parlor (Table 2). Cows milked $6 \times$ for 7,14 , and $21 \mathrm{~d}$ were moved to the pen housing the $3 \times$ cows immediately after their $6 \times$ regimens had ended ( $\mathrm{d} 8,15$, or 22$)$, and all cows were commingled in a single pen at 29 DIM through the remainder of the $305-d$ trial. Use of animals in this investigation was approved by The University of Arizona Institute of Animal Care and Use Committee.

The 5 treatment groups (60 cows/treatment) were: 1 ) cows milked $3 \times$ through 305 DIM, 2) cows milked $6 \times$ for 7 DIM and then $3 \times$ through 305 DIM, 3) cows milked $6 \times$ for 14 DIM and then $3 \times$ through 305 DIM, 4) cows milked $6 \times$ for 21 DIM and then $3 \times$ through 305 DIM, and 5) cows milked $6 \times$ to 21 DIM and then $3 \times$ through 305 DIM. Cows assigned to treatments 1, 2, 3, and 4 were administered rbST (Posilac; Monsanto, St. Louis, MO) at 14-d intervals beginning at $63 \pm 3$ DIM and remained on rbST throughout the 305-d study. Cows in treatment group 5 did not receive rbST. Cows that were assigned to treatments and subsequently removed from the herd or relocated to the hospital pen before completion of the $6 \times$ milking regimen were replaced with other cows. The $3 \times$ group (group 1 ) was milked at 8 -h intervals, and groups 2 to $5(6 \times)$ were milked at 4 -h intervals during the IMF regimen.

\section{Measurements}

Daily milk weights were measured electronically by Boumatic Computer software (Madison, WI) for each animal milking throughout the 305-d lactation. Monthly milk composition analysis and SCC was conducted at Arizona DHIA (Tempe, AZ) using an infrared analyzer (model 2000 and model 500; Bentley Instruments, St. Paul, MN). Energy-corrected milk (ECM) was calculated 
from milk, protein, and fat volumes $(0.327 \times$ milk $\mathrm{kg}+$ $12.95 \times$ fat $\mathrm{kg}+7.2 \times$ protein $\mathrm{kg}$ ). Pen DMI was monitored and recorded using PROFEED2000 (DairyWorks, Tempe, AZ) feed management software. Cows were scored for body condition at freshening and at $28 \pm 4$-d intervals. Body condition scores were based on a 5-point scale (Wildman et al., 1982). Blood samples were collected from the coccygeal vein from a subset of cows $(n=$ 15) from groups 1 and 4 at parturition and then on 7 , 14,21 , and $28 \pm 1 \mathrm{DIM}$, and the harvested plasma was immediately frozen at $-20^{\circ} \mathrm{C}$ until analysis.

Plasma NEFA concentrations were determined enzymatically using commercially available kits validated for use in our laboratory (NEFA C kit; Wako Chemicals USA, Richmond, VA). These procedures were scaled down and conducted in 96-well microtiter plates (Rainin Instrument, LLC, Oakland, CA) and read using a microplate photometer (Multiskan Ascent, Thermo Electron Corporation, Vantaa, Finland) as previously described (Moore et al., 2004). The inter- and intraassay coefficients were 7.4 and 5.7\%, respectively. Samples of TMR were obtained monthly, and wet chemistry analyses were conducted by the Dairy Nutritional Services Laboratory (Tempe, AZ).

\section{Statistical Analyses}

All performance data were analyzed for the first $9 \mathrm{wk}$ PP and then from wk 10 to 44 to evaluate the effects of IMF during early lactation and the potential carryover effects after peak milk. Treatments $1,2,3$, and 4 were analyzed to evaluate the impact of IMF, and treatments 4 and 5 were analyzed separately to determine the impact of $6 \times$ milking for $21 \mathrm{~d} \mathrm{PP}$ with and without rbST administration beginning at 63 DIM. Data were analyzed using PROC MIXED procedures of SAS (SAS Institute, 1999). Previous 305-d mature equivalent milk yields were included as a covariate in the analysis. Daily milk yields were collapsed into weekly averages. Dependent variables tested were milk yield, calculated ECM, BCS, BW, SCC, fat and protein percentages, and yields. The independent variables for milk yield, calculated ECM, BCS, BW, SCC, fat, and protein percentages and yields included treatment, time, and the respective interactions. Time (week of study) was fit as a repeated measure and treatment means were separated using the PDIFF option for all. A $\chi^{2}$ (General Association CochranMantel-Hansen) analysis was done to test for associations of reproductive and herd health variables monitored.

\section{RESULTS}

Cows milked $3 \times$ tended $(P=0.08)$ to produce more milk (43.2 vs. 41.5 and $40.9 \pm 1.1 \mathrm{~kg} / \mathrm{d}$; Figure 1 and
Table 3$)$ and more $(P<0.01)$ ECM $(45.0$ vs. 42.6 and $41.6 \pm 0.7 \mathrm{~kg} / \mathrm{d}$; Table 3 ) during the first 9 wk of lactation compared with cows milked $6 \times$ for 7 or 21 DIM, respectively. Milk yields did not differ among milking frequency treatments $(38.3 \pm 0.7 \mathrm{~kg} / \mathrm{d})$ after wk 9 (Table 3 and Figure 1). Yields of ECM were higher $(P<0.05)$ after wk 9 for cows milked $3 \times$ daily compared with $6 \times$ for 21 DIM (39.1 vs. $38.2 \pm 0.4 \mathrm{~kg} / \mathrm{d}$ ). However, $3 \times$ cows had similar ECM yields as those milked $6 \times$ for 7 or 14 DIM, (38.8 kg/d; Table 3). Percentages of milk fat (3.80 $\pm 0.12)$ and protein $(2.90 \pm 0.06)$ did not differ among treatments during the first $9 \mathrm{wk}$ after calving (Table 3 ). However, cows milked $3 \times$ daily had increased $(P=0.01)$ yields of fat compared with cows milked $6 \times$ for 7 or 21 DIM (1.68 vs. $1.55 \pm 0.05 \mathrm{~kg} / \mathrm{d}$; Table 3). In addition, cows milked $3 \times$ or $6 \times$ for 7 or 14 DIM produced more $(P$ $<0.01)$ protein compared with cows milked $6 \times$ for 21 DIM (1.25 vs. $1.16 \pm 0.03 \mathrm{~kg} / \mathrm{d})$. Somatic cell count (257 $\times 10^{3}$ cells $/ \mathrm{mL}$ ) and BCS (3.60) did not differ between treatments during the first 9 wk after calving (Table 3 ). However, SCC were higher $(P=0.02)$ between wk 10 and 44 for cows milked $3 \times$ and $6 \times$ for 21 DIM compared with cows that were milked $6 \times$ for 14 DIM ( 595 and 526 vs. $294 \times 10^{3} \pm 111 \times 10^{3}$ cells $/ \mathrm{mL}$; Table 3). Plasma NEFA concentrations $(477 \mu \mathrm{Eq} / \mathrm{L})$ did not differ between the $3 \times$ and $6 \times 21-d$ treatments (Table 3 ).

Early lactation milk yield $(41.9 \mathrm{~kg} / \mathrm{d})$ did not differ statistically between cows milked $6 \times$ for 21 DIM that eventually received rbST starting at 63 DIM compared with those not receiving rbST (Table 4 and Figure 2). Cows treated with rbST and milked $6 \times$ for 21 DIM produced more $(P<0.01)$ milk (38.8 vs. $34.2 \pm 0.9 \mathrm{~kg} / \mathrm{d}$; Figure 2) and ECM (39.0 vs. $34.5 \pm 0.4 \mathrm{~kg} / \mathrm{d}$ ) compared with cows milked $6 \times$ for $21 \mathrm{DIM}$ and not provided rbST between wk 10 and 44 of lactation (Table 4). Neither milk fat (3.71) nor protein (2.86) percentages nor yields of fat $(1.56 \mathrm{~kg} / \mathrm{d})$ differed during the first $9 \mathrm{wk}$ after calving between the 2 treatment groups milked $6 \times$ for $21 \mathrm{DIM}$ (Table 4). Average SCC $\left(226 \times 10^{3}\right.$ cell $\left.\mathrm{s} / \mathrm{mL}\right)$ and BCS (3.58) were also similar between the 2 treatments during the first $9 \mathrm{wk}$ after calving. Milk fat and protein content (3.62 and 2.91, respectively) were not affected by rbST administration; however, yields of milk fat (1.37 vs. $1.26 \pm 0.03 \mathrm{~kg} / \mathrm{d})$ and protein (1.12 vs. $1.00 \pm 0.03 \mathrm{~kg} /$ d) were higher $(P<0.01)$ for cows administered rbST and milked $6 \times$ for $21 \mathrm{DIM}$ compared with cows not receiving rbST (Table 4). Overall milk SCC (528 vs. $252 \times 10^{3}$ $\pm 102 \times 10^{3}$ cells $\left./ \mathrm{mL}\right)$ were increased $(P<0.01)$ and BCS decreased (3.53 vs. $3.56 \pm 0.01 ; P<0.05$ ) for cows administered rbST after being milked $6 \times$ for 21 DIM compared with cows milked $6 \times$ for 21 DIM and did not receive rbST at $63 \mathrm{DIM}$. 


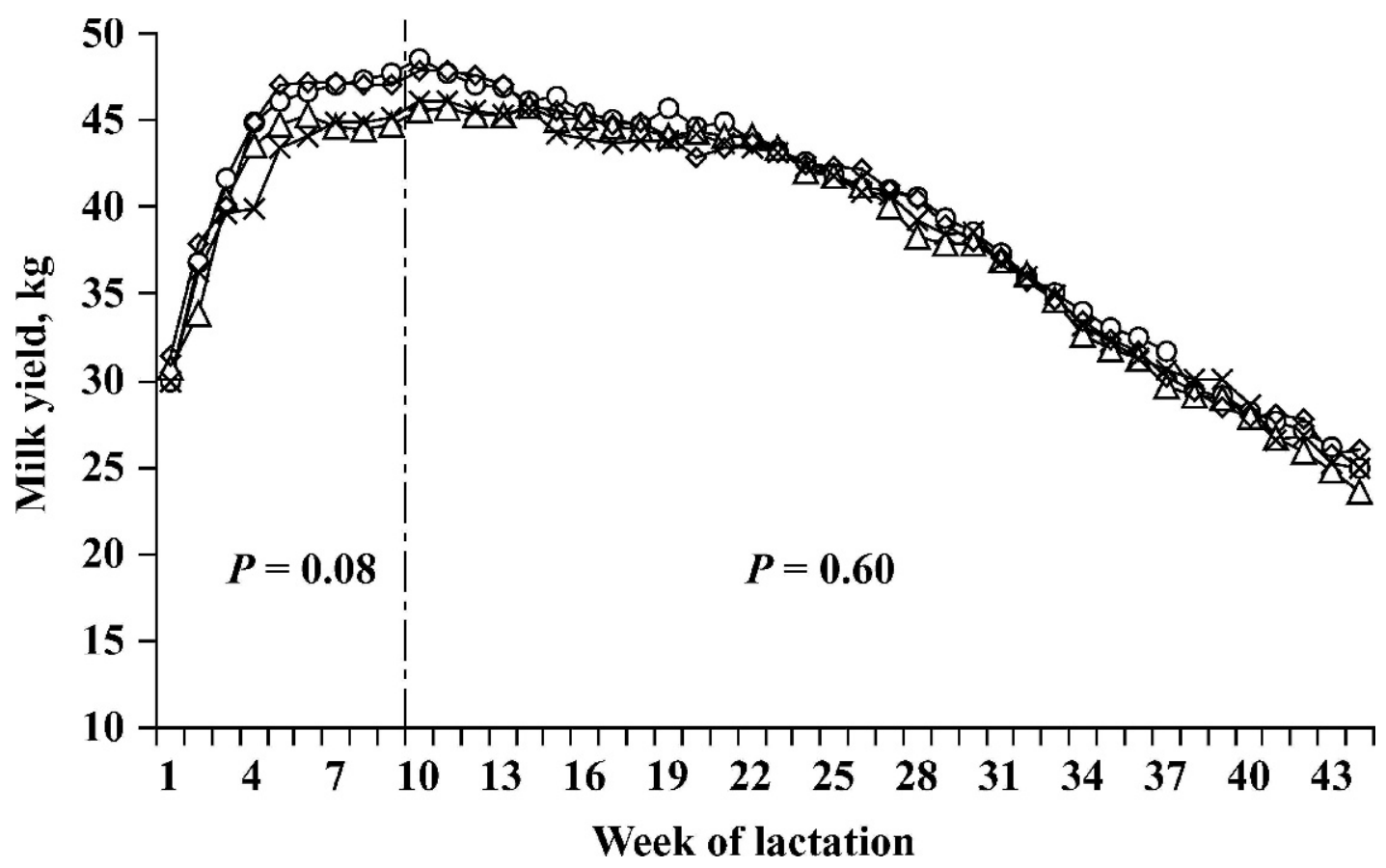

Figure 1. Milk yields during the first 9 wk of lactation and then from wk 10 to 44 postpartum for cows milked 3 (3×) or 6 times daily (6×) for 7, 14, or $21 \mathrm{DIM}$ (vertical dashed line indicates end of wk 9); $\bigcirc=3 \times$ milking, $\triangle=6 \times$ milking for $7 \mathrm{~d}$ postpartum, $\diamond=6 \times$ milking for $14 \mathrm{~d}$ postpartum, $\times=6 \times$ milking for $21 \mathrm{~d}$ postpartum. All cows were milked $3 \times$ daily except for experimental periods in the first 3 wk.

Table 3. Performance of cows milked 3 times (0, control) or 6 times $(6 \times)$ daily for 7,14 , or 21 DIM followed by milking $3 \times$ daily thereafter.

\begin{tabular}{|c|c|c|c|c|c|c|}
\hline \multirow[b]{2}{*}{ Item } & \multirow[b]{2}{*}{0} & \multicolumn{3}{|c|}{$6 \times$ milking $(\mathrm{DIM})$} & \multirow[b]{2}{*}{ SEM } & \multirow[b]{2}{*}{$P$} \\
\hline & & 7 & 14 & 21 & & \\
\hline \multicolumn{7}{|c|}{ First 9 wk postpartum } \\
\hline Milk, kg/d & 43.2 & 41.5 & 43.4 & 40.9 & 1.1 & 0.08 \\
\hline $\mathrm{ECM},{ }^{1} \mathrm{~kg} / \mathrm{d}$ & $45.0^{\mathrm{a}}$ & $42.6^{\mathrm{b}}$ & $44.4^{\mathrm{a}}$ & $41.6^{\mathrm{b}}$ & 0.7 & $<0.01$ \\
\hline Pen $\mathrm{DMI}^{2}$ & 19.3 & 19.4 & 19.4 & 19.4 & - & - \\
\hline Fat, \% & 3.90 & 3.77 & 3.77 & 3.74 & 0.12 & 0.50 \\
\hline Fat, kg/d & $1.68^{\mathrm{a}}$ & $1.56^{\mathrm{bc}}$ & $1.64^{\mathrm{ac}}$ & $1.53^{\mathrm{b}}$ & 0.05 & 0.01 \\
\hline Protein, \% & 2.90 & 2.95 & 2.89 & 2.85 & 0.06 & 0.40 \\
\hline Protein, kg/d & 1.26 & 1.23 & 1.26 & 1.16 & 0.03 & $<0.01$ \\
\hline $\mathrm{SCC}, \times 10^{3} / \mathrm{mL}$ & 347 & 255 & 136 & 288 & 119 & 0.32 \\
\hline BCS & 3.60 & 3.63 & 3.58 & 3.57 & 0.03 & 0.29 \\
\hline NEFA, $\mu \mathrm{Eq} / \mathrm{L}$ & 489 & - & - & 464 & 73 & 0.74 \\
\hline \multicolumn{7}{|l|}{ Wk 9 to 44} \\
\hline Milk, kg/d & 38.7 & 37.9 & 38.5 & 38.1 & 0.7 & 0.60 \\
\hline ECM, kg/d & $39.1^{\mathrm{ac}}$ & $38.3^{\mathrm{ab}}$ & $39.1^{\mathrm{c}}$ & $38.2^{\mathrm{b}}$ & 0.4 & 0.04 \\
\hline Fat, $\%$ & 3.63 & 3.64 & 3.69 & 3.60 & 0.07 & 0.70 \\
\hline Fat, kg/d & 1.41 & 1.38 & 1.42 & 1.37 & 0.03 & 0.27 \\
\hline Protein, \% & 2.93 & 2.95 & 2.95 & 2.93 & 0.04 & 0.82 \\
\hline Protein, kg/d & 1.14 & 1.18 & 1.13 & 1.12 & 0.01 & 0.26 \\
\hline SCC, $\times 10^{3} / \mathrm{mL}$ & $595^{\mathrm{a}}$ & $362^{\mathrm{bc}}$ & $294^{\mathrm{b}}$ & $526^{\mathrm{ac}}$ & 111 & 0.02 \\
\hline $\mathrm{BCS}$ & $3.54^{\mathrm{a}}$ & $3.57^{\mathrm{b}}$ & $3.54^{\mathrm{a}}$ & $3.53^{\mathrm{a}}$ & 0.01 & $<0.01$ \\
\hline
\end{tabular}

a,b,c Means with unlike superscripts within row differ $(P<0.05)$.

${ }^{1} \mathrm{ECM}=$ Energy-corrected milk.

${ }^{2}$ Total feed fed to the $3 \times$ and $6 \times$ pen minus refusals divided by the number of cows in the pen daily. 
Table 4. Production variables of cows milked 6 times (6x) daily for 21 DIM followed by 3 times (3x) daily thereafter, with or without recombinant bST administration.

\begin{tabular}{lcccr}
\hline & \multicolumn{2}{c}{21 DIM of $6 \times$ milking } & & \\
\cline { 2 - 3 } Item $^{1}$ & No rbST & rbST & SEM & $P$ \\
\hline First 9 wk postpartum & & & & \\
Milk, kg/d & 42.9 & 40.9 & 1.18 & 0.12 \\
Energy-corrected milk, kg/d & 43.3 & 41.6 & 0.72 & 0.03 \\
Fat, \% & 3.68 & 3.74 & 0.13 & 0.68 \\
Fat, kg/d & 1.58 & 1.53 & 0.05 & 0.38 \\
Protein, \% & 2.86 & 2.85 & 0.06 & 0.80 \\
Protein, kg/d & 1.22 & 1.16 & 0.02 & 0.02 \\
SCC, $\times 10^{3} / \mathrm{mL}$ & 164 & 288 & 125 & 0.34 \\
BCS & 3.59 & 3.57 & 0.04 & 0.79 \\
Wk 9 to wk 44 & & & & $<0.9$ \\
Milk, kg/d & 34.2 & 38.8 & 0.4 & $<0.01$ \\
Energy-corrected milk, kg/d & 34.5 & 39.0 & 0.07 & 0.63 \\
Fat, \% & 3.64 & 3.60 & 0.03 & $<0.01$ \\
Fat, kg/d & 1.24 & 1.40 & 0.04 & 0.53 \\
Protein, \% & 2.90 & 2.92 & 0.03 & $<0.01$ \\
Protein, kg/d & 1.00 & 1.12 & 102 & 0.01 \\
SCC, $\times 10^{3} / \mathrm{mL}$ & 252 & 328 & 0.01 & 0.03 \\
BCS & 3.56 & 3.53 & & \\
\hline
\end{tabular}

\footnotetext{
${ }^{1}$ Both groups were milked $6 \times$ for 21 DIM and then $3 \times$ thereafter. Starting on $d 63$, recombinant bovine
} somatotropin (rbST) was administered at 14-d intervals to cows in the group scheduled to receive rbST.

The percentage of cows pregnant (37\%) within $65 \mathrm{~d}$ of the voluntary waiting period (80 DIM), average DIM at pregnancy (126), and average service per conception
(2.28) did not differ among treatments $\left(\chi^{2}=0.96\right.$; Table 5). The number of cows that were sent to the hospital pen during the 305-d trial for mastitis (97), digestive

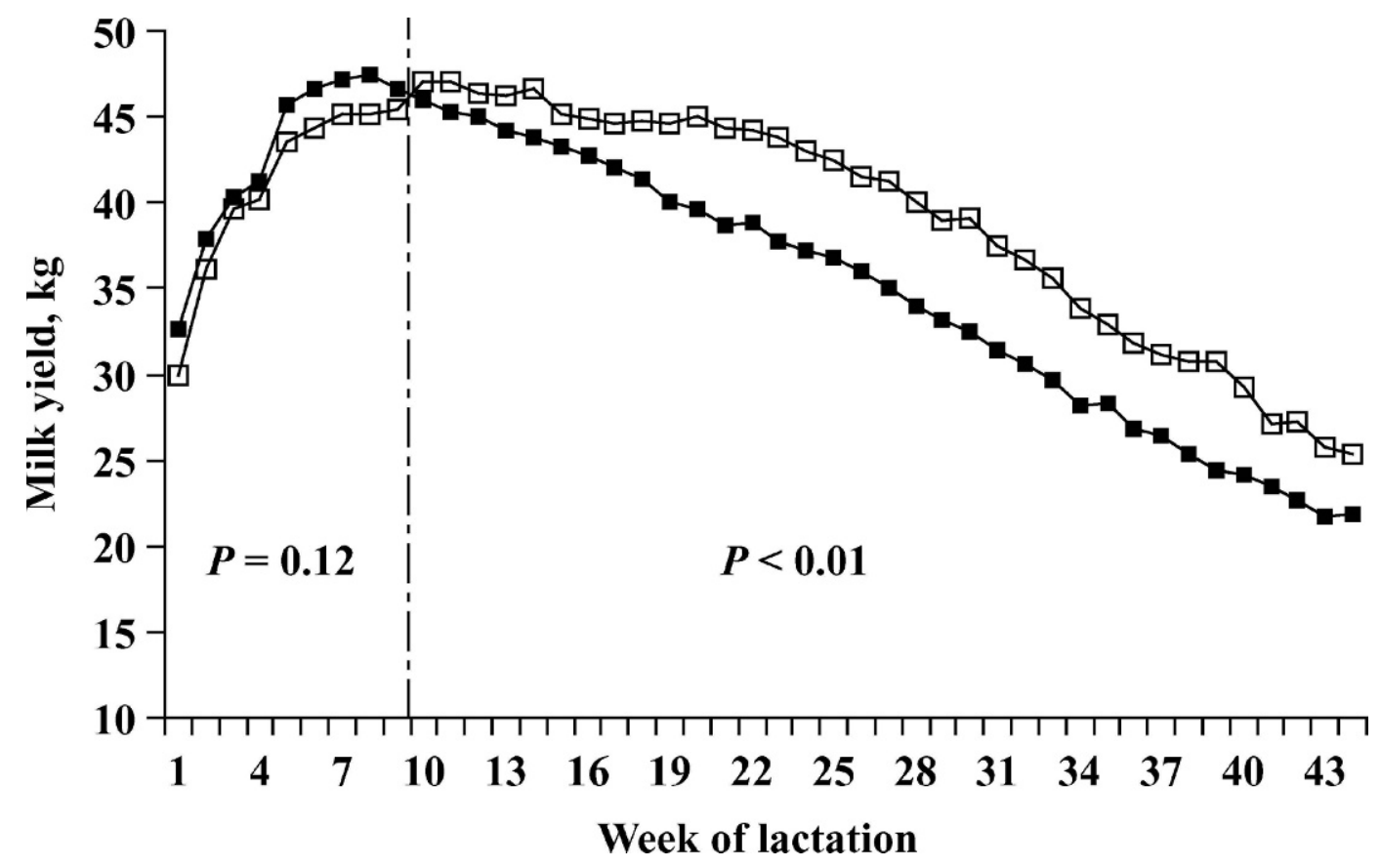

Figure 2. Milk yield of cows milked 6 times daily (6×) for 21 DIM and subsequently receiving or not receiving recombinant bST (rbST) beginning at 63 DIM. Milk yields include the first $9 \mathrm{wk}$ of lactation indicated by vertical dashed line and then wk 10 to 44 postpartum after initiation of injections of rbST; $\square=6 \times$ milking for 21 DIM going to receive rbST beginning at wk 9 , $\square=6 \times$ milking for 21 DIM not going to receive rbST throughout the 44-wk trial. 
Table 5. Reproductive, herd health, and culling measures for cows milked 3 times (0, control) or 6 times (6×) daily for 7,14 , or 21 DIM followed by $3 \times$ milking thereafter.

\begin{tabular}{|c|c|c|c|c|c|}
\hline \multirow[b]{2}{*}{ Item } & \multirow[b]{2}{*}{0} & \multicolumn{3}{|c|}{$6 \times$ milking $(\mathrm{DIM})$} & \multirow[b]{2}{*}{21 (no rbST) } \\
\hline & & 7 & 14 & 21 & \\
\hline \multicolumn{6}{|l|}{ Reproduction } \\
\hline Pregnant by VWP+65 d, ${ }^{1} \%$ & 37 & 43 & 40 & 31 & 32 \\
\hline DIM at pregnant & 125 & 124 & 127 & 127 & 127 \\
\hline Times bred & 2.33 & 2.03 & 2.24 & 2.47 & 2.31 \\
\hline \multicolumn{6}{|c|}{ Cows that visited hospital, ${ }^{2} \%$ (total) } \\
\hline Mastitis & $50(16)$ & $65(22)$ & $58(19)$ & $67(22)$ & $60(18)$ \\
\hline Digestive & $9(3)$ & $9(3)$ & $6(2)$ & $6(2)$ & $13(4)$ \\
\hline Respiratory & $9(3)$ & $6(2)$ & $9(3)$ & $3(1)$ & 0 \\
\hline Lame & $19(6)$ & $15(5)$ & $6(2)$ & $18(6)$ & $10(3)$ \\
\hline Retained placenta & $13(4)$ & $6(2)$ & $12(4)$ & $6(2)$ & $13(4)$ \\
\hline Other $^{3}$ & 0 & 0 & $9(3)$ & 0 & $3(1)$ \\
\hline \multicolumn{6}{|l|}{ Cows that left herd, $\%$ (total) } \\
\hline Diarrhea & $25(1)$ & 0 & 0 & $25(1)$ & $50(2)$ \\
\hline Downer & $14(1)$ & $30(2)$ & $30(2)$ & $14(1)$ & $14(1)$ \\
\hline E. coli mastitis & 0 & $33(2)$ & 0 & $17(1)$ & $51(3)$ \\
\hline Lame & $13(2)$ & $44(7)$ & $13(2)$ & $25(4)$ & $6(1)$ \\
\hline Pneumonia & $50(2)$ & $25(1)$ & $25(1)$ & 0 & 0 \\
\hline Reproduction & $25(1)$ & $25(1)$ & 0 & 0 & $50(2)$ \\
\hline
\end{tabular}

\footnotetext{
${ }^{1}$ Percentage of cows pregnant within $65 \mathrm{~d}$ of the voluntary waiting period (VWP) did not differ across groups $\left(\chi^{2}=0.96\right)$.

${ }^{2}$ Percentage of cows that visited the hospital did not differ across groups $\left(\chi^{2}=0.49\right)$.

${ }^{3}$ Two cows on $6 \times$ milking for 14 DIM were downer cows, and 1 cow had a skin condition; the 1 cow on $6 \times$ milking for 21 DIM without recombinant bST (rbST) treatment was also a downer cow.
}

disorders (14), respiratory issues (9), lameness (22), or retained placenta (16), were not affected by milking frequency or somatotropin treatments $\left(\chi^{2}=0.49\right)$.

\section{DISCUSSION}

During established lactation, IMF consistently enhances milk synthesis. Recent data indicate that IMF during early lactation has an immediate impact on milk yield, and that this response is maintained even after the IMF regimen has ceased. However, previous early lactation IMF studies have not directly evaluated the duration (i.e., DIM) for which IMF needs to be implemented to obtain a beneficial effect on immediate milk yield, peak milk levels, and lactation persistency. We evaluated the effect of milking cows $6 \times$ for as few as 7 , 14, or $21 \mathrm{~d}$ PP; our data indicated that IMF did not enhance milk yield during the IMF regimen $(35.8 \mathrm{~kg} / \mathrm{d})$, or during the first 9 wk of lactation $(42.3 \mathrm{~kg} / \mathrm{d})$, or after wk 9 (wk 10 to $44 ; 38.3 \mathrm{~kg} / \mathrm{d}$ ). This is in contrast to findings by others (Bar-Peled et al., 1995; Sanders et al., 2000), who reported a $7.3-\mathrm{kg}(21 \%)$ and a $6.0-\mathrm{kg} / \mathrm{d}$ increase $(16 \%)$ in production when cows were milked $6 \times$ for 42 DIM compared with $3 \times$. In addition, Hale et al. (2003) milked cows twice vs. 4 times daily during the first 21 DIM, and reported that cows milked 4 times a day immediately postpartum produced up to $8.8 \mathrm{~kg} / \mathrm{d}$ more milk than those milked twice daily during early lactation; this response in lactation persisted until 252
DIM. Additionally, a recent field study using monthly testing indicated that cows milked $6 \times$ for $21 \mathrm{~d}$ PP had increased yields of milk $6.0 \mathrm{~kg} / \mathrm{d}(11 \%)$ during the IMF regimen and milk yield continued to be higher after (carry-over effect) IMF had ceased (Dahl et al., 2004). Because we did not observe an increase in immediate milk production or peak milk yield (Table 3), it was not surprising that we did not detect an IMF effect on lactation persistency (Figure 1).

Milk fat and protein are typically reduced as milking frequency increases as both Smith et al. (2002) and Erdman and Varner, (1995) report decreased milk protein and fat percentages when cows were milked $3 \times$ vs. $2 \times$. In addition, Hale et al. (2003) indicated that IMF in early lactation decreased milk fat and the decrease persisted for the entire lactation. In our study, monthly milk fat (3.8) and protein (2.9) percentages were not affected by IMF during the first 9 wk PP or from wk 10 to 44, which agrees with Bar-Peled et al. (1995) and Sanders et al. (2000). The reported differences in milk fat between the aforementioned studies may be explained by the fact that we did not observe an increase in milk yield or by differences in milk sampling strategies. In our study and others (Bar-Peled et al., 1995; Sanders et al., 2000), milk samples were analyzed monthly (therefore the range in DIM at sampling was $\pm 28 \mathrm{~d}$ ) and there were no differences observed in milk composition, whereas Hale et al. (2003) sampled weekly and detected differences. 
Smith et al. (2002) compiled performance records representing approximately $10,600 \mathrm{cows} / \mathrm{yr}$ (1998 to 2000) and observed an overall decrease in SCC when cows were milked $3 \times$ vs. $2 \times$. However, in our study, milk SCC were not affected by IMF during the first 9 wk PP, which agrees with other IMF trials (Bar-Peled et al., 1995; Sanders et al., 2000; Hale et al., 2003). In contrast to early lactation, during wk 10 to 44 of lactation, cows previously milked $6 \times$ for 7 or 14 DIM did have reduced milk SCC compared with $3 \times$ or $6 \times$ for 21 DIM (Table 3 ); however the biological significance (if any) is difficult to interpret.

Reasons why our IMF milk production data do not agree with others (Bar-Peled et al., 1995; Sanders et al., 2000; Hale et al., 2003; Dahl et al., 2004) are not clear, but facility logistics may have contributed to the discrepancies. Unlike previous reports, where cows were housed in a tie-stall environment or individual pens, or where the influence of facility is not reported, cows used in our study were not individually penned. Instead, they were housed in a dry-lot facility located $87 \pm 36 \mathrm{~m}$ from the milking parlor (Table 2). Thus, cows in the $6 \times$ milking regimen walked to and from the parlor 6 times daily $(1044 \pm 432 \mathrm{~m} / \mathrm{d})$ and spent, on average, $6.5 \mathrm{~h} / \mathrm{d}$ outside their pen. Consequently, they were physically away from feed and water longer than were control animals. This study was carried out under conditions typical to large western commercial dairies, where it is likely that IMF will alter available time for feed and water consumption. Although increased walking may have affected estimated maintenance requirements, the calculated increase was small (1.12 vs. $0.80 \mathrm{Mcal} / \mathrm{d}$; NRC, 2001), and compared with typical large commercial dairies, the total walking distance was nominal even for cows being milked $6 \times$ daily.

Although cows milked $6 \times$ were away from feed longer, average pen DMI per cow during the IMF regimen did not differ $(19.3 \mathrm{~kg} / \mathrm{d})$. In contrast, Bar-Peled et al. (1995) reported an increase in DMI (16.8 vs. $19.4 \mathrm{~kg} / \mathrm{d}$, from 0 to $42 \mathrm{DIM}$; and $20.1 \mathrm{vs.} 22.4 \mathrm{~kg} / \mathrm{d}$ from 49 to $70 \mathrm{DIM}$ ) for cows milked $3 \times$ compared with $6 \times$. Despite the increase in DMI in cows milked 6× (Bar-Peled et al., 1995), both BW and BCS were reduced by $6 \times$ milking. Not surprisingly (because we did not detect milk yield or DMI differences), IMF had little or no effect on early or late-lactation BCS (Table 3). In agreement with our BCS data, IMF had no effect on early-lactation plasma NEFA concentrations (Table 3), a metabolic proxy for adipose mobilization. Incidentally, DMI (for all IMF treatments) immediately postpartum (0 to 21 DIM) in our study was similar to that reported for the cows milked $6 \times$ in BarPeled et al. (1995) in later lactation (i.e., 40 DIM). In contrast to Bar-Peled et al. (1995), our cows consumed similar amounts of feed while experiencing differing IMF regimens. Cows milked $3 \times$ in the current study produced more milk than cows milked $6 \times$ in the Bar-Peled et al. (1995) study, suggesting that perhaps the $3 \times$ milking under conditions used in this experiment maximized the potential for changes in milking frequency to enhance production during early lactation.

Again, the exact reasons why our milking frequency data do not agree with others (Bar-Peled et al., 1995; Sanders et al., 2000; Dahl et al., 2004) are unclear. Inadequate nutritional status is not likely as cows across treatments averaged over $13,000 \mathrm{~kg}$ of $3.5 \% \mathrm{FCM}$ throughout lactation. Furthermore, the nutritional status was likely sufficient as cows had an average BCS of 3.65 and 3.60 at calving and in wk 9 of lactation, respectively. In addition, nutritional status was certainly sufficient during established lactation as exogenous rbST increased (12\%) milk yield consistently throughout lactation (Figure 2). Furthermore, environmental factors such as heat stress were not an issue as the majority of the trial was conducted during the winter (November through March) months and ambient temperature $\left(12 \pm-10^{\circ} \mathrm{C}\right)$ and humidity $(50 \pm 25 \%)$ were low. An explanation may be that cows in all treatments had an average milk production of $35.8 \mathrm{~kg} / \mathrm{d}$ during the first 21 DIM and this is difficult to compare because other studies (Bar-Peled et al., 1995; Sanders et al., 2000) that administered a $6 \times$ milking regimen milked cows $6 \times$ daily through 42 DIM. Consequently, high-producing cows, especially high producers that have a steep slope of milk yield increase, may not be as responsive to increased milking frequency immediately after calving ( $\leq 21 \mathrm{DIM})$. Although Hale et al. (2003) demonstrated an increase in as few as $21 \mathrm{~d}$ after calving, their cows were milked $4 \times$ vs. $2 \times$, not $6 \times$ vs. $3 \times$.

Exogenous bovine somatotropin consistently increases milk yield by 10 to $15 \% / c o w$ (Bauman and Vernon, 1993). In our study, 2 groups of cows were milked $6 \times$ for 21 DIM, and then 1 group received rbST beginning at 63 DIM. Although milking cows $6 \times$ during early lactation and subsequently administering rbST at 63 DIM has not previously been evaluated, combining IMF and rbST in established lactation additively enhances milk yield (Knight et al., 1992). This supports the concept that the 2 galactopoietic tools are additive and probably increase milk synthesis via different mechanisms (Knight et al., 1992; Speicher et al., 1994). We did not see a milk response to IMF, although cows milked $6 \times$ and treated with rbST (wk 10 to 44 ) produced more milk (12\%) and more ECM (12\%) than cows that did not receive rbST.

Percentages of milk fat (3.62) and protein (2.91) were not affected by rbST administration; however, yields of fat ( $1.37 \mathrm{vs} .1 .26 \mathrm{~kg} / \mathrm{d})$ and protein $(1.12 \mathrm{vs} .1 .00 \mathrm{~kg} / \mathrm{d})$ were higher for cows provided rbST and milked $6 \times$ for 21 DIM compared with cows not receiving rbST. Milk somatic cells ( $5.28 \mathrm{vs} .2 .52 \times 10^{3}$ cells $\left./ \mathrm{mL}\right)$ were increased 
and BCS was slightly decreased (3.53 vs. 3.56) for cows given rbST after being milked $6 \times$ for 21 DIM compared with cows not receiving rbST and milked $6 \times$ for 21 DIM. It has been demonstrated that somatotropin does not alter the normal relationship between milk yield and mastitis (White et al., 1994). In the current study, mastitis was the most common reason for cows visiting the hospital pen in all treatments; however, there was no difference in clinical mastitis incidence between cows given $\mathrm{rbST}$ and those not given rbST. As previously reported (White et al., 1994) with respect to mastitis, the performance and health of cows administered rbST appears to be similar to that of cows not administered rbST but yielding similar amounts of milk.

Reproductive variables (cows pregnant within $65 \mathrm{~d}$ of the voluntary waiting period, average DIM at pregnancy, and average service per conception) and the number of cows that were sent to the hospital pen (for mastitis, digestive disorders, respiratory issues, lameness, or retained placenta) were not affected by IMF or by use of somatotropin during our 305-d trial. This suggests that IMF with or without rbST had no influence on animal health and reproductive performance. Therefore, the decision to implement a $6 \times$ milking regimen for 7,14 , or $21 \mathrm{~d}$ PP in an attempt to immediately increase milk synthesis or enhance lactation persistency does not appear to be warranted under the management conditions of the current study.

\section{CONCLUSIONS}

Our data clearly indicate that IMF $(6 \times$ vs. $3 \times)$ during the immediate PP period (7, 14, or 21 DIM) did not affect performance, reproduction, herd health, or culling variables. Cows receiving rbST (at $63 \mathrm{DIM}$ ) produced $4.6 \mathrm{~kg} / \mathrm{d}$ more milk compared with cows milked $6 \times$ for $21 \mathrm{DIM}$ and not administered rbST. Although there is scientific evidence to support $4 \times$ vs. $2 \times$ milking for 21 DIM followed by $2 \times$ milking thereafter or $6 \times$ milking for 42 DIM followed by $3 \times$, our data indicate that $6 \times$ milking for either 7, 14, or 21 DIM is not effective. More research needs to be conducted to determine milking regimens of appropriate frequency and duration to yield optimal short-term and sustained production responses.

\section{ACKNOWLEDGMENTS}

The authors would like to thank the United Dairymen of Arizona (Tempe, AZ), for funding this trial and Mon- santo Dairy Business for making Posilac available during allocation. We appreciate Tom Thompson and the employees of Stotz Dairy for their help, Dave Henderson for statistical support, Sara Sanders for laboratory support, and Arnaldo Burgos of Dairy Nutritional Services (Chandler, AZ) for diet formulations and analysis.

\section{REFERENCES}

Bar-Peled, U., E. Maltz, I. Bruckental, Y. Folman, Y. Kali, H. Gacitua, A. R. Lehrer, C. H. Knight, B. Robinzon, H. Voet, and H. Tagari. 1995. Relationship between frequent milking or suckling in early lactation and milk production of high producing dairy cows. J. Dairy Sci. 78:2726-2736.

Bauman, D. E., and R. G. Vernon. 1993. Effects of exogenous bovine somatotropin on lactation. Annu. Rev. Nutr. 13:437-461.

Dahl, G. E., R. L. Wallace, R. D. Shanks, and D. Lueking. 2004. Hot Topic: Effects of frequent milking in early lactation on milk yield and udder health. J. Dairy Sci. 87:882-885.

Erdman, R. A., and M. Varner. 1995. Fixed responses to increased milking frequency. J. Dairy Sci. 78:1199-1203.

Hale, S. A., A. V. Capuco, and R. A. Erdman. 2003. Milk yield and mammary growth effects due to increased milking frequency during early lactation. J. Dairy Sci. 86:2061-2071.

Kazmer, G. W., M. A. Barnes, R. M. Akers, and W. D. Whittier. 1986. Lactogenic hormone receptors in mammary membrane preparations from prepartum and 60 and 180 day post-partum Holstein cattle. J. Endocrinol. 109:175-180.

Knight, C. H., J. E. Hillerton, M. A. Kerr, R. M. Teverson, A. Turvey, and C. J. Wilde. 1992. Separate and additive stimulation of bovine milk yield by the local and systemic galactopoietic stimuli of frequent milking and growth hormone. J. Dairy Res. 59:243-252.

Moore, C. E., H. C. Hafliger, III, O. B. Mendivil, S. R. Sanders, D. E. Bauman, and L. H. Baumgard. 2004. Increasing amounts of conjugated linoleic acid (CLA) progressively reduces milk fat synthesis immediately postpartum. J. Dairy Sci. 87:1886-1895.

National Research Council. 2001. Nutrient Requirements of Dairy Cattle. 7th rev. ed. Natl. Acad. Sci., Washington, DC.

Sanders, A. H., M. A. Varner, and R. A. Erdman. 2000. The effects of 6 times a day milking in early lactation on milk yield, milk composition, body condition, and reproduction. J. Dairy Sci. 83(Suppl. 1):242.

SAS Institute. 1999. SAS/STAT software, release 6.11. SAS Inst., Inc., Cary, NC.

Smith, J. W., L. O. Ely, W. M. Graves, and W. D. Gilson. 2002. Effect of milking frequency on DHI performance measures. J. Dairy Sci. 85:3526-3533.

Speicher, J. A., H. A. Tucker, R. W. Ashley, E. P. Stanisiewski, J. F. Boucher, and C. J. Sniffen. 1994. Production responses of cows to recombinantly derived bovine somatotropin and to frequency of milking. J. Dairy Sci. 77:2509-2517.

White, T. C., K. S. Madsen, R. L. Hintz, R. H. Sorbet, R. J. Collier, D. L. Hard, G. F. Hartnell, W. A. Samuels, G. deKerchove, F. Adriaens, N. Craven, D. E. Bauman, G. Bertrand, P. H. Bruneau, G. O. Gravert, H. H. Head, J. T. Huber, R. C. Lamb, C. Palmer, A. N. Pell, R. Phipps, R. Weller, G. Piva, Y. Rijpkema, J. Skarda, F. Vedeau, and C. Wollny. 1994. Clinical mastitis in cows treated with sometribove (recombinant bovine somatotropin) and its relationship to milk yield. J. Dairy Sci. 77:2249-2260.

Wildman, E. E., G. M. Jones, P. E. Wagner, R. L. Bowman, H. F. Trout, Jr., and T. N. Lesch. 1982. A dairy cow body condition scoring system and relationship to selected production characteristics. J. Dairy Sci. 65:495-501. 